\title{
Relentless Unfolding: Emerson's Individual
}

\author{
JOHN T. LYSAKER \\ University of Oregon
}

\begin{abstract}
Amid its romantic excesses such as " $[\mathrm{t}] \mathrm{o}$ believe your own thought, to believe that what is true for you in your private heart, is true for all men,- - that is genius" (Porte 2001, 121), Emersonian individualism remains a living project, one we would do well to understand more thoroughly and pursue more rigorously. To aid in this recovery, I will, in a translating repetition of Emerson's thought that engages a range of texts, offer eight theses that any successful reconstruction of individualism must embrace. I am not claiming that these theses are unique to Emerson; others hold similar views. I have elected to work with Emerson, however, because his work eludes the exhausted opposition between atomistic and collectivist accounts of human flourishing. Emerson thinks in severely relational terms. I say "severely relational" because he both denies the possibility of an atomistic self and refuses to dissolve human beings into, or defer our endeavors to, the systemic activities of macrosubjectivities like culture, states, traditional communities, civil-social associations, ecosystems, or even a divinity. Because he broaches the issue of how individuals are private and public, solitary and engaged, Emerson strikes me as a salutary interlocutor for those who would rethink individualism.
\end{abstract}

\section{Individualism Requires Conscious Self-Fashioning}

Permit me a point of stipulation and clarification. In metaphysics, we might speak of singular beings as individuals, and distinguish them from larger collectivities to which they may or may not belong. In this sense,

The Journal of Speculative Philosophy, Vol. 17, No. 3, 2003.

Copyright (C) 2003 The Pennsylvania State University, University Park, PA. 
anything that exists as a categorically distinct entity is an "individual," e.g., a shoe or muskrat. Here, however, I will treat individuals as accomplishments. In this sense, individuality is not a state coextensive with existing, but one that a person might more or less achieve.

In the work of Emerson, we readily find the thought that individuals are accomplishments: "The Intellect still asks that a man be born" (Porte 2001, 82). And: "So many promising youths, and never a finished man" (99). A human being must be born at least twice: once from a womb (of one kind or another), and then again through his or her own hands. The latter activity requires the individuation of forces that inform our being, e.g., language, as well those events that manifest it, such as our beliefs and actions. For example, through my writing and speech, I might develop a style of my own, half lyric ventures, half wisecracks. Thus, to paraphrase Cavell, I might earn the right to say 'I am' by acquiring the capacity to richly say 'I think' (Heller 1986, 282). Or, to draw the thinking thing into more obvious transactions, I might fret that my profession is less mine than some set of demands that one-sidedly shape me. If so, if what we could call individuation is lacking, we may persist as metaphysical individuals but live as replicas.

I speak of individuation because individuality follows from activities such as journaling, friendships, walking in the woods, and buying goods, which enable us to bring our intuitions and inspirations about what to do and believe-e.g., protest an impending war or regard the academy within an archly capitalist social order - to bear on the various modalities of our being - e.g. neighbor, man, teacher, and so forth. In a perhaps broader sense, individuation also entails allowing an emerging sense of self, for instance as a site of ecopolitical becoming, to wash over our many beliefs, actions, and roles, tuning them, as it were, such that they acknowledge who emerges. Or, in more Emersonian terms, we could say that individuation occurs when we subordinate our inheritance to our genius, a point I'll develop below.

\section{Individualism is an Ethical Project}

Addressing Harvard Divinity School, Emerson stated: "The intuition of the moral sentiment is an insight of the perfection of the laws of the soul" (Porte 2001, 70). In the full context of Emerson's writings, this is an abundant passage. At this juncture, however, my point is simple: soul work, for Emerson, must be responsive to moral concerns. Not all influences are desirable; not all beliefs and actions are praiseworthy. Individuation is thus not only a process of translation but also of selection and rejection. We can always ask whether or not we have chosen well. For example, should I champion Emerson in this project, or turn to less canonical, less routinely championed figures? Moreover, given the range of our 
influences, questions of emphasis and rank also pertain. As the "war on everything' continues and a Reich of oil barons looms in the shadows, is this the time to reflect upon and teach issues surrounding the individual? These questions arise because individuation is an ethically bound activity, subject to measures of justice and to considerations of rank concerning its goodness.

Lest you think I am making too much of a passage from the Divinity School address, let me say more about the status of conscience in Emerson's writing. Reflecting on Montaigne and thus on skepticism in the labor of self-cultivation, Emerson writes: "The final solution in which Skepticism is lost is, in the moral sentiment, which never forfeits its supremacy. All moods may be safely tried, and their weight allowed to all objections: the moral sentiment as easily outweighs them all, as any one. This is the drop that balances the sea" (246). Likewise, considering Shakespeare and thus addressing the role of the poet, Emerson chastises Shakespeare because "[h]e rested in . . beauty; and never took the step which seemed inevitable to such genius, namely, to explore the virtue which resides in these symbols ..." (259). For Emerson, then, the moral cannot be bracketed, even through a division of cognitive labor that distinguishes morality from the aesthetic or the theoretical. Instead, we are always morally claimed.

\section{Individuation Must Be Understood Dialectically}

In "The Over-Soul," Emerson writes: "Man is a stream whose source is hidden. Our being is descending into us from we know not whence"(163). We are creatures of inspiration; thoughts come to us on their own rather than in response to our summons. Decisions occur when we find ourselves resolved, not in response to executive orders. I thus regard individuation as a responsive project, one in which we are witnesses to our emergence and the sallies of our genius, only cultivating the former according to the latter after the fact. Foreshadowing Dewey's emphasis on primary experience, Emerson writes: "That which each can do best, none but his [sic] Maker can teach him. No man yet knows what it is, nor can, till that person has exhibited it" (134).

Ontogenetically, this thesis can be put in another way, and with different import. We exist through what we are not. Non-self forces (what Emerson in "Nature" terms the 'not-me'), constitute us, e.g., the books we read, the historical period to which we are born, our town, climate, and so forth. Emerson writes in "Quotation and Originality" that "[t]here is imitation, model, and suggestion, to the very archangels, if we knew their history" (320). Our dependency is not just a matter of intellectual influence, however. In "History," one finds that "[h]e [sic] is the compend of time: he is also the correlative of nature. His power consists in the multitude of his affinities, in the fact that his life is intertwined with the whole chain of organic and inorganic being" (118). Thus when Emerson 
writes in his 1840 journal, "[i]n all my lectures, I have taught one doctrine, namely, the infinitude of the private man" (503), we must be careful not to oppose "private" and "relational." The two intertwine.

These two thoughts, that we are not the authors of what is most intimate to us and that the private opens onto the not-me even as the not-me announces itself to and through the private, have implications for how we think individuation, genius's subordination of our inheritan ces. In "Spiritual Laws," Emerson writes: "Human character evermore publi shes itself. The most fugitive deed and word, the mere doing of a thing, the intimated purpose, expresses character" (159). Keeping to this image, self-cultivation requires that we become expe rt readers of our own publications, whether they are thoughts, actions, or desires. Individuation is thus not simply a willful subordination of the not-me, but also a process of husbanding the various elements and forces that inform our being according to flashes of genius, what Emerson terms "the last fact behind which analysis cannot go."

\section{The Dialectical Nature of Individuation Entails that Becoming an Individual Is Not a Solitary, Atomistic Project}

Let me repeat the above point. In "Quotation and Originality," Emerson insists that "[o]riginal power is usually accompanied by assimilating power" (325). And, more forcefully: "Our best thoughts came from others. We heard in their words a deeper sense than the speakers put into them and could express ourselves in other people's phrases to finer purposes than they knew" (327). In my words, individuation comes into its own through a tran slating repetition. Our social interdependencies are not only textual, however. In a lecture from Conduct of Life, Emerson writes: "You cannot have one well-bred [read 'individuated'-JTL] man without a whole society of such" (Emerson 1904, 149). In other words, individuation must make use of resources that percolate in the texts, practices, institutions, and persons through which we come to ourselves in the first place.

In "The American Scholar," Emerson writes that "[s]o much of nature as he is ignorant of, so much of his own mind does he not yet possess. And, in fine, the ancient precept 'know thyself,' and the modern precept, 'study nature,' become at last one maxim" (Porte 2001, 58). For Emerson, it is not only hum an artifacts and mentors that open us to ourselves. The more-th an-human world also sponsors self-knowledge. As he told a Boston audience gathered to hear him deliver a lecture titled "Human Culture," "[n]atural objects address him [sic]. If he looks at a flower it awakes in him a pleasing emotion. He cannot see a stone, but his fancy and his understanding are attracted to the varieties of its texture and law of its crystallization, until he finds even this rude body is no stranger to him, and though it cannot speak, yet it is the history of the earth down to a period of 
written history" (Whicher et al. 1964, 221). Emerson's point is twofold. The more-than-human world stimulates our capacities, giving us access to ourselves vis-a-vis those capacities. But that same world also addresses us. And in that address, in its story of emanating forms and organisms, we discover that not only does the more-than-human world stimulate our capacities, but our capacities are manifestations of that world as well, say, in the way our eyes interact with light in sight, or the air both carries and is our voice. In its strivings, in what the late Foucault would have regarded as a kind of askesis, individuation must work with and among the full multiplicity of beings and forces whose stamp can be found within us.

\section{Despite its Dialectical Nature, Individuation Requires Spontaneous, Reflective, and Personal Participation}

I take this to be the dialectical pair of the fourth thesis. Although we are creatures of relation, and primordially so, the relation is genuine. We are not simply parts of larger wholes but contribute to the whole. ${ }^{2}$ We thus belong to the whole in our own manner, and it is that particular relation of subject and object that we are that individuation, through translating repetitions guided by genius, must discover and fashion in an ethical manner.

A perhaps unexpected implication of the truly relational nature of individuation as a practice of self-cultivation is that no one can do the labor of self-discovery and self-fashioning for us. This is not just a matter of Emersonian bravado, the kind that berates our inner lemmings because we too often "shun the rugged battle of fate, where strength is born" (Porte 2001, 131). We may rely upon others along the way, whether for illumination or support (say in the form of cash or cheer-I think here of the diverse support Emerson offered the Alcott family). But no one can play our part in individuation. At the close of the initial Boston lecture on culture, Emerson instructed his audience on this point. "I have as much doubt as any one of the value of general rules. There are heights of character to which a man [sic] must ascend alone-not to be foreshown, - that can only exist by the arrival of the man and the crisis" (Whicher et al. 1964, 229).

This point, profound in its import, is more complex than might appear. First, our participation is a necessary if not sufficient part of the project of individuation. As many know from failed intimacies, another cannot persuade us to love. Or, as many know from athletic activities, on some days we try, on others not, and no one can try for us. As Emerson writes in his journal, seeing the matter from the other side: "I can be wise very well for myself, but not for another" (Whicher 1957, 138). Second, who each of us is, and whether we will follow our genius or the path of the toddy cannot be forecast, even by the one who must weather the crisis, understood here as an ever present and always arriving turn- 
ing point. Again, our being descends into us from elsewhere, and thus even should we brace ourselves with a promise, we cannot say how we will acquit ourselves or even what precisely we will face until the moment is upon us, or rather, past. In the work of self-fashioning, then, we are always up for grabs. This is why Emerson is right to say in "Self-Reliance" that "the way, the thought, the good shall be wholly strange and new. It shall exclude example and experience" (Porte 2001, 129). Or, in the lan guage of his lectures entitled "The Philosophy of History": "The simple fact is that wisdom is not transferable, that the wisdom of any past age or person cannot be barrelled up for use today. Always life is to be administered by the new and fresh action of the soul" (Whicher et al. 1964, 166).

\section{A Project of Individualism Requires a Theory of Culture in the Sense of Bildung}

In a journal entry dated March 4,1838 , one that reappears later in his lectures on human culture, Emerson writes: "Culture in the high sense, does not consist in polishing or varnishing, but in so presenting the attractions of nature that the slumbering attributes of man may burst their iron sleep and rush, full grown, into day" (Whicher 1957, 85). On my reading, we awaken slumbering attributes by intimately engaging a set of insights and practices responsive to what were earlier termed the "laws of the soul," e.g., dependency on tradition, participation in multiple hum an and more-than-human ecologies, the solitude of our choices, the muse-like nature of the intuitions to which 'all other teachings are tuitions,' an d so forth. Viewed from afar, such a program in part involves tutelage at the hands of representative characters, other selves whose achievements provoke, instruct, and cheer, for inst ance, Emerson himself, Mother Jones, or Lenin. Up close, however, within the work of individuation, each figure offers, perhaps repeatedly, a point at which our genius will struggle to announce its affirmations and negations, and with a judgment that, strictly speaking, can have no forebears.

We shouldn't abstract encounters with representative characters from larger contexts of interaction, however. Emerson's commitment to public lecturing as well as his jealous concern for time in his study manifests a feel for how various sites and practices facilitate differently the labor of individuation. The larger point, though, is that a theory of Bildung must grapple with its own pragmatics, the sites and practices within which self-experience and self-work unfold. Now, we may have doubts about the effectiveness of public lectures in the face of other circumstances. So does Emerson, who was aware that social forces conspire against self-cultivation. In December of 1837, he wrote. "I need not specify with accusing finger the unsound parts of our social life. A universal pri nciple of compromise has crept into use. A Routine which no $\mathrm{m}$ an made an $\mathrm{d}$ for whose abuses 
no man holds himself accountable tyrannizes over the spontaneous will and character of all individuals" (Whicher et al. 1964, 218). In "The Method of Nature," however, in a lecture delivered in 1841, Emerson pointed a finger.

I do not wish to look with sour aspect at the industrious manufacturing village, or the mart of commerce. . . I I look on trade and every mechanical craft as education also. But let me disc riminate what is precious herein. There is in each of these works an act of invention, an intellectual step, or short series of steps taken; that act or step is the spiritual act; all the re st is mere repetition of the same a thousand times. And I will not be deceived into admiring the routine of $h$ andicrafts and mechanics, how splendid soever the result, any more than I admire the routine of the scholars or the cleric class. . . I would not have the laborer sacrificed to the result,- - I would not have the laborer sacrificed to my convenience and pride, nor to that of a great class of such as me. Let there be worse cotton and better men. (Porte 2001, 81-82)

This passage, still resonant and provocative, makes plain how human beings might lose individuation in stupefying, repetitive activities that have no place for their spontaneous, personal participation, that have no room for genius. But it also evidences an awareness that self-cultivation-and permit me the ironycultivates others. Our account of Bildung must recognize, therefore, not only how individuation requires others for inspiration and support, and how it unfolds within context-bound pragmatics, but also how our own cultivation forms a part of that web of relations that outline the prospects of others. In other words, a program of Bildung need not, in fact cannot, coherently champion self over other.

\section{Individuation Produces Character}

Although reflection is a necessary element of individuation (and here Emerson favors, as "The Poet" shows, the imagination and its loving syntheses over the spying, discursive analyses of the understanding and the speculative flights of reason), individuation culminates less in a conception of oneself than in character, that is, in the dispositions and habits that inform the majority of our conduct (191-92, 187). Emerson announces in "The American Scholar" that "[c]haracter is higher than intellect. Thinking is the function. Living is the functionary. The stream retreats to its source" (63). Given the responsive nature of thought, individuation must work on the dispositions and bearings out of which thoughts emerge, e.g., moods, labor, where and how one walks. friendships, etc. Then one will begin to stand upright, for as we are told in "Self-Reliance," "[t]he force of character is cumulative. All the foregone days of virtue work their health into this (126). And, “[d]o your work and you shall reinforce yourself” (124). 


\section{Individuated Characters Are Perpetually Open to the Future}

In "Nature," Emerson writes: "The health of the eye seems to demand a horizon" (31). Why? We are always arriving. As mortal beings the forces that determine us are not ascertainable as a whole. Adrift in the dialectical relationships that we are, we lack the view from everywhere. Emerson observes in "Circles": "Every ultimate fact is only the first of a new series. Every general law is only a particular fact of some more general law presently to disclose itself" (175). To the degree that we can, we thus need to push beyond what passes for ourselves toward our ever-impending arrival. The problem is not simply a limited perspective, however, but that one fact, Emerson avers, that "the world hates-that the soul becomes" (129). Emerson writes in his journal of 1845, "[m]etamorphosis is the law of the universe. All forms are fluent, and as the bird alights on the bough and pauses for rest, then plunges into the air again on its way, so the thoughts of God pause but for a moment in any form, but pass into a new form" (513). Even for the most diligent self-fashioner human life relentlessly unfolds, and thus we continually face the task of tracing and realigning ourselves amid our own ecstasies, even seeking out conditions that might ignite them.

In another journal entry, this one from the spring of 1846, we find: "You must treat the days respectfully, you must be a day yourself" (513). This suggests that individuation unfolds in a time that gives way. If for Aristotle the good life is measured across the span of a life, for Emerson our pacing is too variable for such an extended regard. Instead, he contents himself with daily bread, writing in "Experience": "Since our office is with moments, let us husband them" (204).

With more time, I might convince you that Emerson's many representative characters (poets, scholars, preachers, skeptics, and so forth) have an appointed time (and mood), and that appreciating each involves acquiring the capacity to open ourselves to particular futures. For example, and here I invoke "Experience," sometimes we don't know where we're heading, and our footing is less than sure. "All things swim and glimmer. ... Ghostlike we glide through nature, and should not know our place again" (198). At these times, when our genius fails, when we are "like millers on the lower level of a stream, when the factories above them have exhausted the water," we must huddle with a humbling insight. "The individual is always mistaken. ... It turns out somewhat new, and very unlike what he [sic] promised himself" (207). This is not mere misery, however; such insights help us resist the foolish consistency of inertia. But skepticism shouldn't freeze us either. Its temperate mood shouldn't prevent us from stepping behind the ". . . screen and sheath in which Pan has protected his well-beloved flower," to invoke "The Poet" (197). In other words, we remain open to the future not only by heeding the mortality of the present, but also by trusting our genius, or rather, in the genius of self-trust. On my reading, then, to take a single day as a figure of individuation is to welcome dawn as well as darkness. When the day dims, we should 
dally among our uncertainties, honest in our id ling. But when our genius flows we should relate to ourselves, in our unfolding, as Emerson relates to one inflamed. "If a man is inflamed and carried away by his thought, to that degree that he forgets the authors and the public, and heeds only this one dream, which holds him like an insanity, let me read his paper, and you may have all the arguments and histories and criticism" (194).

\section{Notes}

1. Due to constraints of time and space, I will not engage in any systematic fashion the various scholars, most notably Stanley Cavell, who are also working to recover Emerson. An artificial solitude thus surrounds this paper. Second, I have referenced Emerson's Prose and Poetry (Porte 2001) wherever possible so that a reader might turn to Emerson's texts with greater ease.

2. I would add that this thought marks more of a problem for Emerson than the conclusion of an argument. In a journal entry dated May 26, 1837, he writes: "Who shall define to me an Individual? I behold with awe and delight the many illustrations of the One Universal Mind. I see my being imbedded in it. As a plant in the earth so I grow in God. I am only a form of him. ... A believer in Unity, yet I behold two. . . . Cannot I conceive the Universe without a contradiction?" (Whicher 1957, 62).

\section{Works Cited}

Emerson, Ralph Waldo. 1904. Complete Works: Volume 6. Boston: Houghton Mifflin.

Heller, Thomas C., et al., eds. 1986. Reconstructing Individualism. Stanford: Stanford UP.

Porte, Joel, and Saundra Morris, eds. 2001. Emerson's Prose and Poetry. New York: W. W. Norton and Company.

Whicher, Stephen, et al., eds. 1964. The Early Lectures of Ralph Waldo Emerson: Volume 2, 1836-1838. Cambridge, MA: Harvard UP.

Whicher, Stephen, ed. 1957. Selections from Ralph Waldo Emerson. Boston: Houghton Mifflin. 